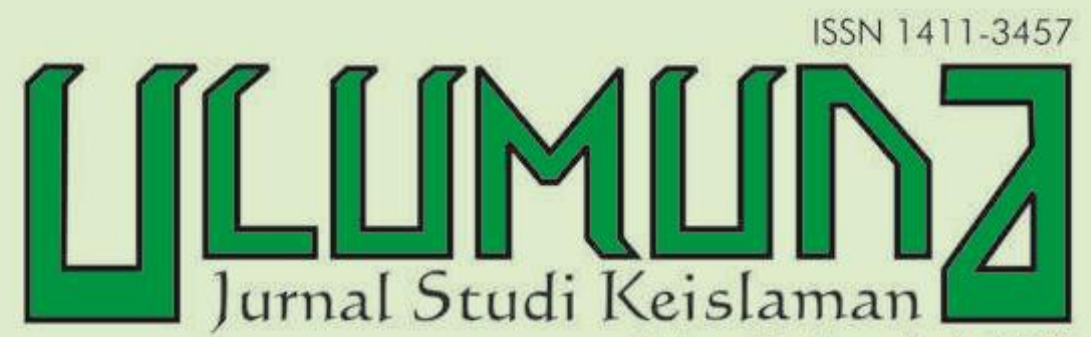

Volume $17 \cdot$ Nomor $1 \cdot$ Juni 2013

TERAKREDITASI B: SK Dirjen Dikti Kemdikbud Nomor: 56/DIKTI/Kep/2012, Tanggal 24 Juli 2012

MENCERNA AKAR FILSAFAT DALAM ISLAM Ismail Fahmi Arrauf PERKEMBANGAN PARADIGMA EPISTEMOLOGI DALAM FILSAFAT ISLAM Fathul Mufid EPISTEMOLOGI ISLAM: KEDUDUKAN WAHYU SEBAGAI SUMBER ILMU Anwar Muiahidin DARI ISLAMISASI ILMU MENUJU PENGILMUAN ISLAM: MELAWAN HEGEMONI EPISTEMOLOGI BARAT Ismail Toib dan Mukhlis INDUKTIVISME SEBAGAI BASIS PENGEMBANGAN ILMU PENGETAHUAN DALAM ISLAM Masdar Hilmy

PERTAUTAN ONTOLOGI FILSAFAT DAN TASAWUF: PERSPEKTIF TENTANG RELASI TUHAN, MANUSIA, DAN ALAM Hadarah Rajab PERTAUTAN EPISTEMOLOGI FILSAFAT DAN TASAWUF: TELAAH SISTEM PEMIKIRAN ABDUL HALIM MAHMUD Lalu Muchsin Effendi ETIKA DALAM FILSAFAT ISLAN:

PEMIKIRAN FILOSOF MUSLIM TENTANG KEBAHAGIAAN Mustain PEngembangan Sumber Daya MANusia DALAM PERSPEKTIF EPESTIMOLOGI FILSAFAT ISLAM Asep Kumiawan 


\section{DAFTAR ISI}

\section{Pedoman Transliterasi}

1-18 • Ismail Fahmi Arrauf,

"Mencerna Akar Filsafat dalam Islam"

19-40 • Fathul Mufid,

"Perkembangan Paradigma Epistemologi

dalam Filsafat Islam"

41-64 • Anwar Mujahidin

"Epistemologi Islam:

Kedudukan Wahyu Sebagai Sumber Ilmu"

65-96 • Ismail Toib dan Mukhlis

"Dari Islamisasi Ilmu Menuju Pengilmuan Islam:

Melawan Hegemoni Epistemologi Barat"

97-126 • Masdar Hilmy

"Induktivisme Sebagai Basis Pengembangan

Ilmu Pengetahuan dalam Islam"

127-152 • Hadarah Rajab

"Pertautan Ontologi Filsafat dan Tasawuf:

Telaah Relasi Tuhan, Manusia, dan Alam"

153-190 • Lalu Muchsin Effendi

"Pertautan Epistemologi Filsafat dan Tasawuf:

Telaah Sistem Pemikiran Abdul Halim Mahmud"

191-212• Mustain

"Etika dan Ajaran Moral Filsafat Islam:

Pemikiran Para Filosof Muslim tentang Kebahagiaan"

\section{3-230 • Asep Kurniawan}

Pengembangan Sumber Daya Manusia

dalam Perspektif Epestimologi Filsafat Islam

\section{APENDIKS}




\section{PEDOMAN TRANSLITERASI}

\begin{tabular}{|c|c|c|c|c|c|c|}
\hline 1 & $=$ & $\mathbf{a}$ & $\dot{\varepsilon}$ & $\dot{\varepsilon}$ & $=$ & $\mathrm{g}$ \\
\hline ب & $=$ & $\mathbf{b}$ & & ف & $=$ & $\mathbf{f}$ \\
\hline$ت$ & $=$ & $t$ & & ق & $=$ & $q$ \\
\hline$\dot{H}$ & $=$ & th & & ك5 & $=$ & $\mathbf{k}$ \\
\hline ج & $=$ & $\mathfrak{j}$ & & j & $=$ & 1 \\
\hline$\tau$ & $=$ & ḥ & & b & $=$ & $\mathbf{m}$ \\
\hline$\dot{\tau}$ & $=$ & $\mathbf{k h}$ & & ن & $=$ & $\mathbf{n}$ \\
\hline د & $=$ & d & & و & $=$ & $\mathbf{w}$ \\
\hline$\dot{j}$ & $=$ & dh & $\circ$ & ○ & $=$ & $\mathbf{h}$ \\
\hline$\jmath$ & $=$ & $\mathbf{r}$ & & $\varepsilon$ & $=$ & , \\
\hline j & $=$ & $\mathbf{z}$ & & ي & $=$ & $\mathbf{y}$ \\
\hline س & $=$ & $\mathrm{s}$ & & & & \\
\hline 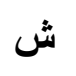 & $=$ & sh & \multicolumn{4}{|c|}{ Untuk Madd dan Diftong } \\
\hline ص - ص & $=$ & ș & i & $=$ & \multicolumn{2}{|c|}{$\bar{a}$ (a panjang) } \\
\hline ض & $=$ & d & إي اي & $=$ & \multicolumn{2}{|c|}{$\overline{1}$ (i panjang) } \\
\hline$b$ & $=$ & $\mathrm{t}$ & أو - & $=$ & \multicolumn{2}{|c|}{$\overline{\mathrm{u}}$ (u panjang) } \\
\hline ظ & $=$ & $\mathrm{z}$ & او - او & $=$ & \multicolumn{2}{|c|}{ aw } \\
\hline$\varepsilon$ & $=$ & 6 & أي & $=$ & \multicolumn{2}{|l|}{ ay } \\
\hline
\end{tabular}

Contoh penulisan dengan transliterasi:

اعوذ بالله من الشيطان الرجيم (a'üdhu bi al-Lāh min al-shaytān al-rajim);

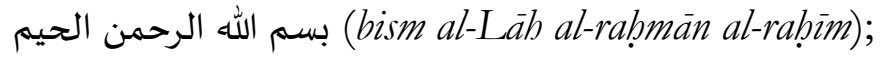

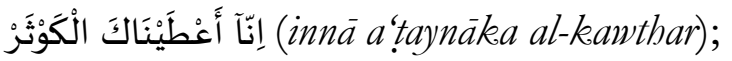

(fasalli lirabbika wanhar);

صباح الخير (șabāh al-khayr). 


\title{
PERTAUTAN ONTOLOGI FILSAFAT DAN TASAWUF: TELAAH RELASI TUHAN, MANUSIA, DAN ALAM
}

\author{
Hadarah Rajab
}

(STAIN Syekh Abdurrahman Siddik, Bangka Belitung

Email: hadarah.rajab@yahoo.com)

Abstract: Ontology dwells on the issue of how to explain substance, the nature of all that exists. Substance itself is an actual reality, not an artificial, deceiving, and changing reality. Since philosophy and mysticism are talking about substance, both fields of Islamic scholarship have a relationship to one another at an ontological level. This paper aims to elaborate interconnection between them. Elaborating the interconnection, the author analyzes the ontological aspects of al-Gazali's sufism and Naqsyabandiah tariquah. The author concludes that the ontological interconnection between both disciplines are very closely from the standpoint of the relation of God, man, and nature.

Abstract: Ontologi berkutat pada persoalan bagaimana menerangkan bakikat dari segala yang ada. Hakikat termasuk dalam kajian ontologi. Hakikat adalah realitas atau kenyataan yang sebenarnya, bukan kenyataan sementara, yang menipu dan berubah. Baik filsafat maupun tasawuf sama-sama berbicara tentang hakikat, dan oleh sebab itu dua bidang keilmuan Islam memiliki pertautan antara satu dengan lainnya pada level ontologis. Tulisan ini bertujuan untuk mengelaborasi kebertautan antara keduanya itu. Untuk menelisik kebertautan itu, penulis menganalisis aspek-aspek ontologis dalam tasawuf al-Gazali dan tarekat Naqsyabandiah. Penulis menyimpulkan babwa kebertautan ontologis antara dua bidang ilmu sangat erat dari sudut pandang relasi Tuhan, manusia, dan alam.

Keywords: ontologi, rasio, qalb, roh, sirr, sufisme, relasi, Tuhan, manusia, alam 
ONTOLOGI merupakan salah satu di antara lapangan penyelidikan kefilsafatan yang paling kuno. Awal mula alam pikiran Yunani telah menunjukkan munculnya perenungan di bidang ontologi yang diperkenalkan oleh Thales. Perenungannya terhadap air merupakan substansi terdalam yang merupakan asal mula dari segala sesuatu.

Persoalan ontologi adalah persoalan bagaimanakah menerangkan hakikat dari segala yang ada. Pertama kali orang dihadapkan pada adanya dua macam kenyataan. Yang pertama, kenyataan yang berupa materi (kebendaan) dan kedua, kenyataan yang berupa rohani (kejiwaan). ${ }^{1}$ Pembicaraan tentang hakikat sangatlah luas, yaitu segala yang ada dan yang mungkin ada. Hakikat adalah realitas, realitas adalah ke-real-an, riil artinya kenyataan yang sebenarnya. Jadi hakikat adalah kenyataan sebenarnya sesuatu, bukan kenyataan sementara atau keadaan yang menipu, juga kenyataan yang berubah. ${ }^{2}$

Sebuah contoh tentang hakikat makna demokrasi dan fatamorgana. Pada hakikatnya pemerintahan demokratis menghargai pendapat rakyat. Mungkin orang pernah menyaksikan pemerintah melakukan tindakan sewenangwenang, tidak menghargai pendapat rakyat. Itu hanyalah keadaan sementara, bukan hakiki, yang hakiki pemerintahan itu demokratis. Tentang hakikat fatamorgana dicontohkan, melihat suatu objek fatamorgana apakah riil atau tidak, jawabnya tidak, fatamorgana itu bukan hakikat, hakikat fatamorgana itu ialah tidak ada. ${ }^{3}$ Ontologi sebagai dasar ilmu berusaha untuk menjawab "apa" yang menurut Aristoteles merupakan The First Philosophy dan merupakan ilmu mengenai esensi benda. ${ }^{4}$ Kata ontologi berasal dari perkataan Yunani, On yaitu being, dan logos adalah logic. Jadi ontologi menurut James K. Feibleman yang dikutip Bakhtiar ${ }^{5}$ adalah The theory of being qua being (teori tentang

${ }^{1}$ Ahmad Tafsir, Filsafat Umum (Bandung: Remaja Rosdakarya, 2007), 131. 131.

${ }^{2}$ Amsal Bakhtiar, Filsafat Ilmu (Jakarta: Raja Grafindo Persada, 2004),

${ }^{3}$ Tafsir, Filsafat..., 24.

${ }^{4}$ Ibid.

5Ibid. 
keberadaan sebagai keberadaan). Louis O. Kattsoff dalam Elements of Philosophy ${ }^{6}$ mengatakan, ontologi itu mencari ultimate reality dan menceritakan bahwa di antara contoh pemikiran ontologi adalah pemikiran Thales bahwa airlah yang menjadi ultimate substance yang mengeluarkan semua benda. Jadi asal semua benda hanya satu yaitu air. Noeng Muhadjir dalam bukunya Filsafat Ilmu mengatakan, ontologi membahas tentang yang ada, yang tidak terikat oleh satu perwujudan tertentu. Ontologi membahas tentang yang ada yang universal, menampilkan pemikiran semesta universal. Ontologi berusaha mencari inti yang termuat dalam setiap kenyataan, atau dalam rumusan Lorens Bagus, menjelaskan yang ada meliputi semua realitas dalam semua bentuknya. ${ }^{7}$ Sedangkan menurut Jujun S. Sumantri ontologi membahas apa yang ingin diketahui, seberapa jauh rasa ingin tahu atau dengan perkataan lain suatu pengkajian mengenai teori tentang "ada". 8

Menurut A. Dardiri dalam bukunya Humaniora, Filsafat, dan Logika mengatakan ontologi adalah menyelidiki sifat dasar dari apa yang nyata secara fundamental dan cara yang berbeda di mana entitas dari kategori-kategori yang logis yang berlainan (objek-objek fisis, hal universal, abstrak) dapat dikatakan ada; dalam kerangka tradisional ontologi dianggap sebagai teori mengenai prinsip-prinsip umum dari hal ada, sedangkan dalam hal pemakainnya akhir-akhir ini ontologi dipandang sebagai teori mengenai apa yang ada. ${ }^{9}$

Term ontologi pertama kali diperkenalkan oleh Rudolf Goclenius pada tahun $1636 \mathrm{M}$. Untuk menamai teori tentang hakikat yang ada yang bersifat metafisis. Dalam perkembangannya Christian Wolff (1679-1754 M) membagi metafisika menjadi dua, yaitu metafisika umum dan metafisika khusus. Metafisika umum dimaksudkan sebagai istilah lain dari ontologi. Dengan demikian, metafisika umum atau ontologi

\section{${ }^{6}$ Ibid.}

${ }^{7}$ Noeng Muhadjir, Metode Penelitian Kualitatif (Yogyakarta: Rake Sarasin, 2001), 57.

8Jujun S. Sumantri, Filsafat Ilmu Sebuah Pengantar Populer (Jakarta: Pustaka Sinar Harapan, 2003), 5.

'Ibid., 17. 
adalah cabang filsafat yang membicarakan prinsip yang paling dasar atau paling dalam dari segala sesuatu yang ada. Sedang metafisika khusus masih dibagi menjadi; kosmologi, psikologi, dan teologi. ${ }^{10}$

\section{Pokok Pemikiran Pemahaman Ontologi}

Kosmologi adalah cabang filsafat yang secara khusus membicarakan tentang alam semesta. Psikologi adalah cabang filsafat yang secara khusus membicarakan tentang jiwa manusia. Teologi adalah cabang filsafat yang secara khusus membicarakan Tuhan. ${ }^{11}$ Di dalam pemahaman ontologi dapat dikemukakan pandangan-pandangan pokok pemikiran tentang monisme, dualisme, pluralisme, nihilisme, dan agnostisisme.

\section{Monisme}

Paham ini menganggap bahwa hakikat yang asal dari seluruh kenyataan itu hanyalah satu, tidak mungkin dua. Haruslah satu hakikat saja sebagai sumber yang asal, baik yang asal berupa materi atau pun berupa rohani. Tidak mungkin ada hakikat masing-masing bebas dan berdiri sendiri. Haruslah salah satunya merupakan sumber yang pokok dan dominan menentukan perkembangan yang lainnya. Istilah monisme oleh Thomas Davidson disebut dengan block universe. ${ }^{12}$ Paham ini kemudian terbagi kedalam dua aliran; materialisme dan idealisme. Aliran materialisme menganggap bahwa sumber yang asal itu adalah materi bukan rohani. Aliran ini sering disebut dengan naturalisme. Menurutnya bahwa zat mati merupakan kenyataan dan satu-satunya fakta. ${ }^{13}$ Yang ada hanyalah materi, yang lainnya seperti jiwa dan ruh bukan merupakan suatu kenyataan yang berdiri sendiri. Jiwa atau ruh itu hanyalah merupakan akibat dari proses gerakan kebenaran dengan salah satu cara tertentu.

Dari segi dimensinya, paham ini sering dikaitkan dengan teori Atomisme. Menurut teori ini semua materi tersusun dari sejumlah bahan yang disebut unsur. Unsur-unsur itu bersifat

\footnotetext{
${ }^{10}$ Bakhtiar, Filsafat..., 135.

${ }^{11}$ Ibid., 542.

${ }^{12}$ Ibid.

13Ibid., 70 .
} 
tetap, tidak dapat dirusakkan. Bagian-bagian yang terkecil dari unsur itulah yang dinamakan atom-atom. Atom dari unsur sama rupanya dan sebaliknya. Namun perbedaan hanya mengenai berat dan besarnya. Mereka bisa bersatu menjadi molekul yang terkecil dari atom-atom itu. Selanjutnya atom-atom dengan kesatuannya molekul-molekul itu bergerak terus menuruti undang-undang tertentu. ${ }^{14}$ Jadi materialisme menganggap bahwa kenyataan ini merupakan suatu mekanisme seperti suatu mesin yang besar.

Aliran pemikiran di atas dipelopori oleh bapak filsafat yaitu Thales (624-546 SM). Ia berpendapat bahwa unsur asal adalah air karena pentingnya bagi kehidupan. ${ }^{15}$ Anaximander (585-528 SM) berpendapat bahwa unsur asal itu adalah udara dengan alasan bahwa udara merupakan sumber dari segala kehidupan. ${ }^{16}$ Demokritus (460-370 SM) berpendapat bahwa hakikat alam ini merupakan atom-atom yang banyak jumlahnya, tak dapat dihitung dan amat halus. Atom-atom inilah yang merupakan asal kejadian alam. ${ }^{17}$

Dalam perkembangannya, sebagai aliran yang paling tua, paham ini timbul dan tenggelam seiring roda kehidupan manusia yang selalu diwarnai dengan filsafat dan agama. Alasan mengapa aliran ini berkembang sehingga memperkuat dugaan bahwa yang merupakan hakikat adalah, 1). Pada pikiran yang masih sederhana; apa yang kelihatan yang dapat diraba, biasanya dijadikan kebenaran terakhir. Pikiran sederhana tidak mampu memikirkan sesuatu di luar ruang yang abstrak. 2). Penemuanpenemuan menunjukkan betapa bergantungnya jiwa pada badan. Oleh sebab itu, peristiwa jiwa selalu dilihat sebagai peristiwa jasmani. Jasmani lebih menonjol dalam peristiwa ini. 3). Dalam sejarahnya manusia memang bergantung pada benda seperti pada padi. Dewi Sri dan Tuhan muncul dari situ. Kesemuanya ini memperkuat dugaan bahwa yang merupakan hakikat adalah benda.

${ }^{14}$ Sumantri, Filsafat..., 53.

${ }^{15}$ Tafsir, Filsafat..., 29.

${ }^{16}$ Ibid.

${ }^{17}$ Sumantri, Filsafat..., 64. 
Idealisme, sebagai lawan materialisme adalah aliran idealisme yang dinamakan juga dengan spiritualisme. Idealisme berarti serba cita, sedang spiritualisme berarti serba ruh. Idealisme diambil dari kata "idea", yaitu sesuatu yang hadir dalam jiwa. Aliran ini beranggapan bahwa hakikat kenyataan yang beraneka ragam itu semua berasal dari ruh (sukma) atau sejenis dengannya, yaitu sesuatu yang tidak berbentuk dan menempati ruang. Materi atau zat itu hanyalah suatu jenis dari pada penjelmaan ruhani. ${ }^{18}$ Alasan aliran ini yang menyatakan bahwa hakikat benda adalah ruhani, spirit atau sebangsanya adalah nilai ruh lebih tinggi dari pada badan, lebih tinggi nilainya dari materi bagi kehidupan manusia. Ruh ini dianggap sebagai hakikat yang sebenarnya. Sehingga materi hanyalah badannya, badannya atau penjelmaan saja. Manusia lebih dapat memahami dirinya dari pada dunia luar dirinya. Materi ialah kumpulan energi yang menempati ruang. Benda tidak ada, yang ada energi itu saja.

\section{Dualisme}

Aliran ini menganggap bahwa hakikat itu ada dua yang disebut dualisme. Aliran ini berpendapat bahwa benda terdiri dari dua macam hakikat sebagai asal sumbernya, yaitu hakikat materi dan hakikat ruhani, benda dan ruh, jasad dan spirit. Materi bukan muncul dari ruh dan ruh bukan muncul dari benda. Samasama hakikat. Kedua macam hakikat itu masing-masing bebas dan berdiri sendiri, sama azali dan abadi. Hubungan keduanya menciptakan kehidupan dalam alam ini. Contoh yang paling jelas tentang adanya kerja sama kedua hakikat ini ialah dalam diri manusia. ${ }^{19}$

Descartes (1596-1650 M) yang dianggap sebagai bapak filsafat modern memandang terdapat dua hakikat dengan istilah dua kesadaran yaitu ruhani dan dunia ruang (kebendaan). Ini tercantum dalam bukunya Discours de la Methode (1637) dan Meditation de Prima Philosophia (1641). Dalam buku ini pula ia menuangkan metodenya yang terkenal dengan Cogito Descartes (metode keraguan Descartes/Cartesian Doubt). Di samping Descartes ada juga Benedictus De Spinoza (1632-1677 M) dan

${ }^{18}$ Ibid., 56.

${ }^{19}$ Tafsir, Filsafat..., 30. 
Gitifried Wilhem Von Leibniz (1646-1716 M).20 "Aku" yang sedang ragu ini disebabkan oleh "aku" berpikir. Kalau begitu "aku" berpikir pasti ada dan benar. Jika berpikir ada berarti "aku" ada sebab yang berpikir itu "aku". Cogito ergo sum atau "aku" berpikir jadi "aku" ada. Paham ini kemudian terkenal dengan rasionalisme, yaitu paham filsafat yang mengatakan bahwa akal (reason) adalah alat terpenting dalam memperoleh pengetahuan dan mengetas pengetahuan. ${ }^{21}$

\section{Pluralisme}

Paham ini berpandangan bahwa segenap macam bentuk merupakan kenyataan. Pluralisme bertolak dari keseluruhan dan mengakui bahwa segenap macam bentuk itu semuanya nyata. ${ }^{22}$ Pluralisme dalam Dictionary of Philosophy and Religion dikatakan sebagai paham yang menyatakan bahwa kenyataan alam ini tersusun dari banyak unsur, lebih dari satu atau dua entitas. Tokoh aliran ini pada masa Yunani Kuno adalah Anaxagoras dan Empedocles yang menyatakan bahwa substansi yang ada itu terbentuk dan terdiri dari empat unsur, yaitu tanah, air, api, dan udara. $^{23}$

William James (1842-1910 M) kelahiran New York dan terkenal sebagai seorang psikolog dan filosof Amerika. Dalam bukunya The Meaning of Truh mengemukakan, tiada kebenaran yang mutlak yang berlaku umum, yang bersifat tetap, yang berdiri sendiri, lepas dari akal yang mengenal. Sebab pengalaman berjalan terus, dan segala yang dianggap benar dalam perkembangan pengalaman itu senantiasa berubah, karena dalam prakteknya apa yang dianggap benar dapat dikoreksi oleh pengalaman berikutnya. Oleh karena itu, tiada kebenaran yang mutlak, yang ada adalah kebenaran-kebenaran yaitu apa yang

${ }^{20}$ Harun Hadiwijono, Sari Sejarah Filsafat Barat (Yogyakarta: Kanisius, 1980), 18.

${ }^{21} \mathrm{~K}$. Bertrand Russell, Sejarah Filsafat Barat dan Kaitannya dengan Kondisi Sosio-Politik dari Zaman Kuno Hingga Sekarang, ter. Sigit dkk. (Yogyakarta: Pustaka Pelajar, 2001), 45.

${ }^{22}$ Ibid., 70.

23Ibid., 591. 
benar dalam pengalaman-pengalaman yang khusus, yang setiap kali dapat diubah oleh pengalaman berikutnya. ${ }^{24}$

\section{Nibilisme}

Nibilisme berasal dari bahasa Latin yang berarti nothing atau tidak ada. Sebuah doktrin yang tidak mengakui validitas alternatif yang positif. Istilah nibilisme diperkenalkan oleh Ivan Turgeniev dalam novelnya Fathers and Children yang ditulisnya pada tahun 1862 di Rusia. Namun doktrin tentang nibilisme sebenarnya sudah ada semenjak zaman Yunani Kuno, yaitu pada pandangan Gorgias (483-360 SM) yang memberikan tiga proposisi tentang realitas. Pertama, tidak ada sesuatu pun yang eksis. Realitas itu sebenarnya tidak ada. Kedua, bila sesuatu itu ada, ia tidak dapat diketahui. Ini disebabkan oleh penginderaan itu tidak dapat dipercaya, penginderaan itu sumber ilusi. Akal juga tidak mampu meyakinkan tentang bahan alam semesta ini karena telah dikungkung oleh dilema subjektif. Seseorang berpikir sesuai dengan kemauan, ide yang diterapkan pada fenomena. Ketiga, sekalipun realitas itu dapat diketahui ia tidak akan dapat diberitahukan kepada orang lain. ${ }^{25}$

\section{Agnostisisme}

Paham ini mengingkari kesanggupan manusia untuk mengetahui hakikat benda. Baik hakikat materi maupun hakikat ruhani. Kata Agnosticisme berasal dari bahasa Grik. Agnostos yang berarti unknown. Artinya not, Gno artinya know. ${ }^{26}$ Timbulnya aliran ini dikarenakan belum dapatnya orang mengenal dan mampu menerangkan secara konkret akan adanya kenyataan yang berdiri sendiri dan dapat dikenal. Aliran ini dengan tegas selalu menyangkal adanya suatu kenyataan mutlak yang bersifat trancendent. ${ }^{27}$

Aliran Agnosticisme dapat ditemui dalam filsafat eksistensialisme dengan tokoh-tokohnya seperti, Soren Kierkegaar, Heidegger, Sarte, dan K. Jaspers (1883-1969 M) menyangkal adanya suatu

\footnotetext{
${ }^{24}$ Hadiwijono, Sari..., 133.

${ }^{25}$ Tafsir, Filsafat..., 515.

26Bertens, History..., 89.

${ }^{27}$ Ibid., 60 .
} 
kenyataan yang transenden. Yang mungkin itu hanyalah manusia berusaha mengatasi dirinya sendiri dengan membawakan dirinya yang belum sadar kepada kesadaran yang sejati, namun suatu yang mutlak (trancendent) itu tidak ada sama sekali. ${ }^{28}$

\section{Yang Ada (Being)}

Yang 'ada' sering berhubungan dengan dua istilah yaitu esensi dan eksistensi. Seseorang mengatakan segala sesuatu apapun halnya bersifat 'yang ada'. Atau singkatnya, barang sesuatu itu 'ada'. Istilah ini diterapkan kepada segala sesuatu, hakikatnya atau jenisnya. Ilmu membahas mengenai jangkauan pengalaman manusia yang berkaitan dengan fungsi ilmu itu sendiri dalam kehidupan manusia. Ruang penjelajahan keilmuan kemudian menjadi kapling-kapling berbagai disiplin keilmuan, maka setiap ilmuan harus tahu benar batasan-batasan penjelajahan cabang keilmuannya masing-masing. Mengenal batas-batas kapling ini, disamping menunjukkan kematangan keilmuan dan profesional seseorang. ${ }^{29}$

Pandangan ontologi mengalami perkembangan yang tokoh utamanya antara lain Rene Descartes (1596-1650), John Locke (1632-1714), dan George Berkeley (1685-1753). Ketiga ahli filsafat ini berpendapat bahwa apa yang ditangkap oleh pikiran, termasuk penginderaan dari segenap pengalaman manusia, adalah bersifat mental. Bagi Descartes yang bersifat nyata adalah pikiran sebab dengan berpikirlah maka sesuatu itu ada (cogito ergo sum).

John Locke sendiri menganggap bahwa pikiran manusia pada mulanya dapat diibaratkan sebuah lempeng lilin yang licin (tabula rasa) di mana pengalaman indera kemudian melekat pada lempeng tersebut. Makin lama makin banyak pengalaman indera yang terkumpul dan kombinasi dari pengalaman-pengalaman indera ini seterusnya membuahkan ide yang semakin lama semakin rumit. Demikian Berkeley terkenal dengan pernyataannya, To be is to be perceived (ada adalah disebabkan persepsi). ${ }^{30}$ Manusia adalah medium terjadinya peristiwa-

\footnotetext{
${ }^{28}$ Sumantri, Filsafat..., 92.

${ }^{29}$ Ibid., 92.

${ }^{30}$ Ibid., 68.
} 
peristiwa yang ada, maka langkah metodologis yang terawal adalah membuka struktur eksistensial atau kategori-kategori fundamental ujud manusia dengan metode yang disebut "fenomenologis eksistensial" yang identik dengan lingkaran bermeneutis. ${ }^{31}$

Menurut Notonagoro, hakikat manusia adalah untuk melakukan perbuatan-perbuatan lahir dan batin atas dorongan kehendak, berdasarkan atas putusan akal, selaras dengan rasa untuk memenuhi hasrat-hasrat sebagai ketunggalan, yang ketubuhan, yang kejiwaan, yang perseorangan, yang kemakhlukkan sosial, yang berkepribadian berdiri sendiri, yang kemakhlukkan Tuhan. Maka dalam setiap perbuatan manusia terjelma unsur hakikatnya dalam sifatnya kebhinneka-tunggalan, sifatnya majemuk-tunggal atau monopluralis. ${ }^{32}$

Ajaran ontologi tasawuf dan tarekat Naqsyabandiyah melukiskan kodrat kenyataan, ketunggalan hakikat Ilahi, alamatalamat dari yang hakiki dan kodrat manusia. Sebagaimana Sayyed Hosen Nasr melihat bahwa keseluruhan ajaran tasawuf terdiri dari empat bagian, yaitu: metafisika, kosmologi, psikologi, dan harapan eskatologi. Ajaran kosmologi tidak menerangkan detaildetail fisika dan kimiawi, tetapi membahas tentang alam keseluruhan dengan tujuan penjelajahan yang akhirnya dimiliki, dilintasi menghindari perangkap-perangkap bendawi sehingga mampu menangkap cahaya di atas benda-benda dan pada akhirnya sampai pada keadaan hilangnya kekaburan dan kegelapan yang lazim. Ajaran psikologi memuat penyembuhan sakit jiwa secara lengkap dalam perjalanan batin (rohani) atau jiwa menuju pusatnya sendiri untuk selanjutnya menuju penyucian diri dan surga, dan ajaran eskatologi mengandung petunjuk perjalanan menuju pada tingkat hidup yang lain untuk mendapatkan keluasan hidup di balik kehidupan empiris dunia fisikal ini. ${ }^{33}$

Menurut al-Ghazali ilmu ladunni berdasarkan pada prinsip ilmu yaqin sebagai ilmu yang bisa menyingkapkan objeknya dengan keterbukaan yang tidak menyisakan keraguan sedikit pun

\footnotetext{
${ }^{31}$ Ibid., 47.

${ }^{32}$ Ibid., 96.

${ }^{33}$ Nasr Syeed Hussein, Living Sufism (London: Paperback, 1980), 33-5.
} 
dan tidak dihantui oleh kemungkinan keliru dan salah duga (wham). ${ }^{34}$ Demikian dalam tarekat Naqsyabandiyah ilmu tersebut dianggap sebagai ilmu tertinggi yakni tingkatan para wali atau orang-orang yang mendalami ilmunya (ar-rasikhun). Al-Ghazali memandang setiap ilmu yang diraih oleh manusia, tetapi tidak berdasarkan prinsip di atas, ilmu itu tidak bisa dipercaya sama sekali dan tidak terjamin dari kekeliruan, dan ilmu yang tidak terjamin keamanannya tidak bisa disebut sebagai ilmu yakin. ${ }^{35}$

Pandangan ontologi tasawuf al-Ghazali yang menjadi dasar ontologi tarekat Naqsyabandiyah, memandang manusia mempunyai identitas esensial yang tetap, tidak berubah-ubah yaitu al-nafs atau jiwa. ${ }^{36}$ Al-nafs adalah "substansi yang berdiri sendiri dan tidak bertempat" serta merupakan tempat bersemayamnya pengetahuan-pengetahuan intelektual (alma'qulat) yang berasal dari alam malakut atau alam al-amr. ${ }^{37} \mathrm{Hal}$ ini menunjukkan bahwa esensi manusia bukan fisiknya dan bukan fungsi fisik. Al-Ghazali menegaskan bahwa manusia terdiri atas dua substansi pokok, yakni substansi yang berdimensi yang dinamakan badan (al-jism) dan substansi yang tidak berdimensi namun mempunyai kemampuan merasa dan bergerak dengan kemauan, itulah yang disebut (al-nafs). ${ }^{38}$

Pada diri manusia terdapat tiga jiwa (al-nufus al-tsalatsab). Pertama, jiwa tumbuhan (al-nafs al-nabatiyab) merupakan tingkatan jiwa paling rendah dan memiliki tiga daya; nutrisi, tumbuh, dan reproduksi. Kedua, jiwa hewan (al-nafs al-hayawaniyab) yang memiliki dua daya; penggerak, persepsi. Ketiga, jiwa rasional (alnafs al-natiqah) memiliki dua daya; praktis dan teoritis. ${ }^{39}$

Ontologi tarekat Naqsyabandiyah berhubungan dengan pengetahuan sufistik yang oleh al-Ghazali juga dinamakan nur

${ }^{34}$ Hilal Ibrahim, Tasawuf antara Agama dan Filsafat, ter. Ija Suntana dan E. Kusdian (Bandung: Pustaka Hidayat, 1997), 93.

${ }^{35} \mathrm{Abu}$ Hamid Al-Ghazali, Al-Munqis min al-Dhalal (Beirut: Al-Sya'biyah, tt), 84-5.

${ }^{36}$ Abu Hamid Al-Ghazali, Al-Misykat al-Anwar (Kairo: Abu al'Ala Affifi, 1968), 19.

${ }^{37}$ Ibid.

${ }^{38}$ Amin Syukur, Menggugat Tasawuf (Yogyakarta: Pustaka Pelajar, 2002), 171.

${ }^{39} \mathrm{Al}-\mathrm{Ghazali,}$ Al-Misykat..., 56. 
(cahaya) yang didapatkan melalui petunjuk langsung (nubuwab). Menurut analisa Annemarie Schimmel, teori cahaya ini menjadi titik tolak dan rujukan bagi pengembangan tasawuf teosofi seperti; Hikmah Ilahiyah Ibn Arabi, Hikmah Isyraqiyah Suhrawardi. Al-Ghazali menjelaskan bahwa pengertian "nur" bisa berbedabeda sesuai dengan tingkat dan golongan orang yang memberi pengertian tersebut, sebab pada akhirnya akan ditentukan pula oleh daya serap yang digunakan. Bagi orang awam yang daya serapnya bertumpu pada penglihatan lahir yaitu indra penglihatan akan berbeda dengan golongan khawas yang menggunakan penglihatan batin. ${ }^{40}$ Golongan terakhirlah yang dapat menangkap Nur Hakiki yaitu Allah Swt., sebagai nur tertinggi dan terakhir serta sumber segala nur (nur al-anwar). ${ }^{41}$

\section{Tuban dan Relasinya}

Sebagaimana tugas metafisika adalah menemukan makna yang ada secara konkret, untuk menemukan jawaban tentang makna yang ada harus diselidiki yang ada itu sendiri. ${ }^{42}$ Demikian Agama, secara ontologi dan doktrinal bagi seluruh penganutnya, menurut al-Jabiri, secara esensial dianggap sebagai jalan menuju kebahagiaan di akhirat, jalan ini melalui dunia. Agar agama menjadi jalan menuju kebahagiaan akhirat maka ia haruslah sesuai untuk segenap zaman dan tempat. ${ }^{43}$

Berangkat dari kesepakatan para penganut agama Islam bahwa Islam sebagai penutup agama-agama samawi, maka pemahaman yang mendasar tentang hakikat Islam sangatlah penting. Hal ini agar mampu mendudukkan Islam benar-benar sebagai petunjuk Ilabi yang diperuntukkan manusia di bumi ini sebagai pengemban amanat kekhalifahan dibawah naungan normativisme al-Qur'an dan Sunnah.

Ibn 'Arabi memberikan isyarat bahwa beragamnya alam ini disebabkan adanya berbagai realitas tak terlihat (raqiqah) yang menghubungkan manusia dengan Penciptanya. Aspek-aspek

\footnotetext{
${ }^{40}$ Ibid., 42.

${ }^{41}$ Syukur, Menggugat..., 179.

${ }^{42}$ Ibid., 44.

${ }^{43}$ Mohamed Abed Al-Jabiri, Problem Peradaban: Penelusuran atas Jejak Kebudayaan (t.tp: tp, 2004), 270.
} 
khusus ini tentunya berbeda-beda dalam diri setiap manusia. Perbedaan aspek khusus inilah yang menimbulkan perbedaan ilmu Nabi Musa (dengan tongkatnya dapat membelah lautan), ilmu Nabi Khaidhir yang Nabi Musa melontarkan protes keras atas diri Nabi Khaidhir yang melakukan perusakan perahu, membunuh anak kecil, dan membetulkan tembok yang akan runtuh, karena Musa tidak memahami hikmah di balik pekerjaan yang dilakukan oleh Khaidhir. Oleh sebab itu, Khaidhir berkata kepada Musa, "Semua pekerjaan ini dilakukan di atas pengetahuan yang tidak terjangkau olehmu". Demikian penegasan Allah Swt. dalam Qs. al-Mujadalah (58): 11): “Allah akan meninggikan orang-orang yang berilmu di antara kamu dan orangorang yang diberi ilmu pengetahuan beberapa derajat". Masing-masing dari kedua nabi itu mempunyai aspek khusus yang menghubungkan dirinya dengan Allah. Aspek inilah setiap orang memperoleh ilmunya sendiri-sendiri. Musa mempunyai ilmu yang dianugerahkan Allah kepadanya yang tidak dimiliki oleh Khaidhir. Akan tetapi, betapapun tinggi ilmu manusia, ia tetap tidak akan dapat dipakai untuk mengetahui zat al-Haqq. Sebab, ilmu yang dipakai untuk mengetahui al-Haqq sangat mustahil dimiliki oleh selain Allah. ${ }^{44}$ Sama dengan ungkapan al-Ghazali "tidak ada yang mengetahui Allah selain Allah sendiri".

Ahmad Tafsir mengutip sebuah kisah Rasulullah saw. yang berhubungan dengan "hikmah" dengan menggunakan mistikmagis-putih yaitu tatkala Abu Bakar disengat binatang berbisa di Gua Tsur saat mereka bersembunyi di sana. Rasullah saw. membacakan beberapa ayat al-mu'awwidzatain (surat al-Nas dan al-Falaq) kemudian menyemburkannya pada luka sengatan dan atas izin Allah sembuh seketika. Kenyataan seperti ini masih dipraktikkan sampai sekarang oleh pemegang mistik-magis-putih yang sering disebut sebagai abli hikmah. Penyebutan abli hikmah bagi mereka merupakan suatu esensi yang mendasari kegiatan itu secara filosofis: mereka dekat dengan Tuhan dan mengetahui bikmah kedekatan itu. ${ }^{45}$

${ }^{44}$ Ibid., 321.

${ }^{45}$ Tafsir, Filsafat..., 115-6. 
Filsafat Perenial (filsafat Islam) mengatakan bahwa eksistensi-eksistensi tertata secara hirarkis. ${ }^{46}$ Realitas selalu saling terkait, jumlahnya meningkat ketika levelnya naik. Semakin tinggi eksistensi, maka semakin nampak keberadaannya. ${ }^{47}$ Melalui filsafat Perenial disadari adanya yang infinite di balik kenyataan ini (level of reality). Juga dalam diri manusia (level of selfhood) yang terdiri dari body, mind, and soul, dipercayai adanya yang disebut spirit (roh). Alam semesta dan manusia pada dasarnya hanyalah tajalli atau penampakan infinite atau spirit yang dalam Islam disebut al-Haq. ${ }^{48}$ Karena adanya dua level ini maka diyakini dunia ini bersifat hirarkis. Wujud real menurut alegori Plato terdapat di balik bayangan yang nampak, sebab orang sebagai pemilik banyangan lebih real dari pada bayangannya. ${ }^{49}$

Inti alegori itu adalah untuk menggambarkan kemungkinan adanya sesuatu kehidupan yang lebih tinggi yang sekarang sulit dipahami karena manusia tidak mampu ikut serta dalam penampakannya. Manusia dikelilingi oleh benda-benda, bendabenda itu membatasi manusia untuk meningkat ke kualitas lebih tinggi itu dengan kemampuan "cahaya". Dengan demikian, jelaslah bahwa ada hirarki realitas. ${ }^{50}$

Akhir-akhir ini filsafat mengalami perkembangan pada Pos Modern (Post Modern Philosophy) yang ingin menyelamatkan budaya Barat. Menurut mereka budaya Barat dapat diselamatkan bila disusun ulang tidak hanya berdasarkan rasionalisme. Orangorang Posmo berpendapat bahwa sumber kebenaran tidak hanya rasio, ada sumber kebenaran lain selain rasio misalnya Agama, jika digunakan agama maka rasio telah termasuk di dalamnya. ${ }^{51}$ Relasi antara agama dan rasio dapat diejawantahkan dalam aspek pengembangan ilmu pengetahuan serta peningkatan kualitas manusia.

${ }^{46}$ Ibid., 19.

${ }^{47}$ Smith, Margaret, Rabi'a the Mystie and Her Fellow-Saints in Islam (London: Cambridge Univercity Press, 1979), 8.

${ }^{48}$ Komaruddin Hidayat, Agama Masa Depan: Perspektif Filsafat Perenial (Jakarta: Paramadina, 1995), xxxii.

${ }^{49}$ Tafsir, Filsafat..., 72.

${ }^{50}$ Ibid., 74.

${ }^{51}$ Ibid., 79-80. 
Di lain pihak, walaupun aliran idealisme tepat untuk pilihan ontologi bagi ilmuwan yang mempunyai komitmen terhadap Islam, namun karena dalam aliran ini terdapat suatu pemikiran kefilsafatan yang tidak sesuai dengan ajaran Islam, aliran ini sangat menghargai akal manusia seakan-akan menjadi super, maka perlu dikembalikan kepada ajaran Islam, dalam arti menambah catatan, ajaran Islam mengakui keterbatasan akan manusia. Dengan demikian idealisme ditingkatkan menjadi idealisme Ketuhanan dalam arti Islam. ${ }^{52}$

Pandangan Islam bukan berarti menolak ilmu pengetahuan dari Barat. Tetapi akan mengisi dengan nilai-nilai agama khususnya Islam secara menyeluruh (bolistik) yang bersumber dari al-Qur'an dan al-Hadis. Dengan demikian maka dasar ontologinya bahwa hakikat pengetahuan adalah petunjuk dari Tuhan, dalam arti ilmu berdasarkan intelek yang dapat mengetahui esensi yang mengarahkan rasio untuk membentuk ilmu yang ditopang oleh kesadaran dan keimanan terhadap kekuasaan Tuhan dalam slogam para guru tarekat Naqsyabandiyah bahwa, "kenalilah diri kalian dengan baik setelah itu kalian dapat mengenal Tuhan kalian dengan amat baik" (man arafah nafsabu faqad arafab rabbabu).

Al-Ghazali membandingkan antara cara meraih ilmu indrawi dalam akal dan ilmu eksoteris (al-ilm al-kharij) melalui alat indrawi. Perbandingan itu didasarkan pada kenyataan bahwa manusia merupakan duplikat alam atau dalam ungkapan lain disebutkan bahwa manusia adalah alam kecil yang berhadapan dengan alam besar. Al-Ghazali mengumpamakan hati dengan sebuah kolam yang digali di atas tanah melalui selokan-selokan kecil yang mengalirkan air kepadanya. Atau mungkin pula kolam itu digali dasarnya sampai mendekati sumber air yang bersih, lalu darinya memancarkan air. Air dari dasar kolam itu, tentu saja lebih jernih. Alirannya berlangsung lebih lama, lebih deras, dan lebih banyak dari pada air yang kedua. ${ }^{53}$

\section{Ontologi sebagai Dasar Pengetahuan Sufisme}

52Ibid., 18.

${ }^{53} \mathrm{Ibrahim}$, Tasawuf..., 94. 
Ontologi sebagai dasar pengetahuan, merupakan asas dalam menetapkan batasan atau ruang lingkup wujud yang menjadi objek penelaahan (objek formal pengetahuan) serta penafsiran tentang hakikat realitas dari objek formal tersebut. Dalam ilmu tasawuf yang dipraktekkan oleh kalangan tarekat Naqsyabandiyah dikenal tiga alat untuk berkomunikasi secara rohaniah, yaitu qalbu untuk mengetahui sifat-sifat Tuhan, roh untuk mencintai Tuhan, dan sirr untuk musyahadab yakni menyaksikan keindahan, kebenaran, dan kemuliaan Tuhan secara yakin. Ketiga unsur itu sebenarnya menyatu, kesatuan itu secara umum disebut hati. Jika hati tersebut dikosongkan dari segala sesuatu yang buruk dan diisi dengan drikrullah, maka hati itu akan mencapai pengetahuan yang disebut dengan ladunni. ${ }^{54}$ Pada tingkat teologis, sufi berbicara perihal "ampunan, keagungan, dan keindahan" Tuhan jauh melebihi perbincangan mereka mengenai "kemurkaan, kekerasan, dan kemegahan-Nya" yang memainkan peranan penting dalam fiqhi (yurisprudensi) maupun kalam (teologi dogmatis). ${ }^{5}$

\section{Hubungan Manusia dengan Tuhan (Hablun Minallab), Manusia dengan Manusia (Hablun Minannas)}

Tauhid atau keesaan Tuhan telah ditafsirkan secara berbeda oleh para ahli. Karena itu, didapatkan dalam perspektif teologis, seperti yang tercermin dalam konsep tanzih al-shifat-Nya Mu'tazilab; tauhid dalam perspektif filosofis yang menyatakan bahwa pada diri Tuhan, esensi dan eksistensi adalah identik. Demikian juga diperoleh konsep tauhid dalam perspektif sufistik. Tidak seperti pada umumnya yang mengartikan kalimat la ilaha illa Allah Swt. sebagai tidak ada Tuhan selain Allah Swt., para sufi mengartikan kata ilah sebagai realitas, sehingga kalimat syahadat itu bermakna tidak ada realitas (haqiqab) yang sejati kecuali Allah. Dari sini mereka memahami hanya Allah-lah yang real yang hakiki (substantif) sedangkan yang lainnya adalah semu dan nisbi.

${ }^{54}$ Tafsir, Filsafat..., 153.

55John. L. Espisito, Ensiklopedi Oxford, Dunia Baru Islam, ter. Eva Y.N. dkk. (Bandung: Mizan, 2002), 207. 
Untuk membahas tarekat sangat penting mengkaji tauhid yang berhubungan dengan hal ini, sehingga akan lebih jelas dasar pijakan tarekat tersebut. Pandangan Abdurrahim Nur, tauhid itu ada dua macam: tauhid rububiyyah dan tauhid 'ulubiyyah. Tauhid rububiyyah adalah tauhid tentang rabbil 'alamin yakni Tuhan seluruh alam. Sebagaimana dinyatakan dalam surat al-fatihah, alhamdu lillabi rabbil 'alamin, bermakna bahwa alam semesta, alam secara keseluruhan tanpa kecuali, alam apa, alam kapan, alam mana saja, semuanya itu mempunyai aturan dan tatanan. Adapun yang menata, mengatur, menentukan, menetapkan tidak lain kecuali Allah Swt. Jadi ini tentang Rabb-nya. Misalnya, 5+3 pasti $=8$. Sedangkan 5-3 = 2 itu suatu aturan. Contoh lain, suatu benda yang dibenturkan dengan benda tentu akan mengeluarkan bunyi. Tangan ketika dibenturkan dengan meja kayu akan mengeluarkan bunyi yang berbeda dengan ketika dibenturkan dengan besi. Keluarnya bunyi dan perbedaan bunyi tersebut merupakan suatu undang-undang, suatu aturan, ketentuan, ketetapan. Dari mana ketetapan atau aturan itu, tidak ada lain kecuali dari Allah Swt. Jadi adanya bunyi, dan adanya perbedaan bunyi, itu karena ada rabb Allah Swt. Tatanan, aturan, kepastian, bagaimanapun, itu hanya dari Allah Swt. Ini yang disebut tauhid rububiyyah. ${ }^{56}$

Dari tauhid rububiyyah, seseorang bisa dikatakan apakah ia sudah bertauhid atau belum. Kalau dinyatakan sudah bertauhid, itu artinya bertauhid rububiyyah. Tetapi kalau ada orang yang mengatakan bahwa suatu ketetapan bukan bersumber dari Allah Swt., melainkan bersumber dari si Anu, nyi Anu, atau mbah Anu, itu artinya belum bertauhid secara rububiyyah, melainkan dia masih tergolong musyrik. Musyrik dalam konteks ini adalah musyrik rububiyyah yang artinya tidak bertauhid secara rububiyyah.

Sedangkan tentang tauhid ulubiyyah yakni mendasarkan pemahamannya seperti pada surat al-Nas (Ilahi an-Nas). Di sini ada ilah, yang benar "sesembahan". Dan sesembahan yang dimaksud seperti yang tertera dalam semua kata ilah di dalam alQur`an adalah dimaksudkan hanya kepada Allah Swt. Sesembahan itu sendiri sering dinamakan ibadah dan ibadah itu

${ }^{56}$ Abdurrahim Nur, Pergolakan Muhammadiyah Menuju Sufi (Yogyakarta: Hikam Press, 2003), 53-4. 
merupakan suatu sikap, yakni sikap menerima, menyerah, tunduk, patuh sepenuhnya kepada Allah Swt. Beribadah dengan benar akan menjadikan sikap seseorang menjadi la syarika labu wabidzalika umirtu wa ana awwalu al-muslimin: "Tiada sekutu bagiNya dan demikian itulah yang diperintabkan kepadaku, dan aku adalah orang yang pertama-tama menyerahkan diri kepada Allah SWT)".

Kedudukan ilah ini dipandang tinggi sehingga digunakan sebagai pernyataan awal seseorang yang akan memeluk Islam yakni kalimat syahadab: la ilaha ila Allab bukan 'la rabba ill Allab'. Karena yang dimaksud di sini adalah tentang sesembahan yang di dalamnya menyangkut juga tentang aturan, maka logika yang dibentuk adalah apabila sudah menyatakan bahwa segala sesuatu aturan itu bersumber hanya kepada Allah Swt., maka pengabdian tentu juga seharusnya hanya kepada Allah Swt.

Dari sini dapat disimpulkan apabila seseorang telah bersikap bahwa Allah Swt. adalah ilah maka Allah Swt. sebagai rabb secara otomatis terikutkan. Tidak demikian halnya bila terjadi sebaliknya, bila seseorang mengakui Allah Swt., sebagai rabb, ilah belum tentu dengan sertamerta terikutkan. Karena itu bertauhid haruslah keduanya yakni bertauhid secara rububiyyah dan bertauhid secara ilabiyah.

Jadi seseorang dikatakan sudah bertauhid apabila ia sudah bertauhid rububiyyah dan 'ulubiyyah secara murni. Dalam berakidah, orang seperti ini akan bersikap menerima, tunduk, patuh, dan taat hanya kepada Allah Swt. semata. Orang yang demikian inilah sesungguhnya yang disebut dengan sufi yakni berarti murni, mulus, bersih, jernih. Jadi orang yang sufi adalah orang yang sudah bertauhid secara struktural maupun fungsional. Jelasnya bertauhid rububiyyah secara struktural dan fungsional serta bertauhid secara 'uluhiyyah secara struktural dan fungsional. 57

Sebaliknya seseorang belum dikatakan sebagai sufi apabila dalam peribadatannya masih tercemari oleh benih-benih kemusyrikan. Karena sesungguhnya yang demikian itu tauhidnya belum murni. Misalnya di dalam shalat, akan menyatakan bahwa, sesunggubnya shalatku, ibadabku, bidupkeu, dan matiku, hanyalah untuk Allah Swt. Tuhan semesta alam. Demikian firman-Nya dalam Qs.

${ }^{57}$ Ibid., 55. 
Al-An'am (6): 162, “Katakanlab: Sesunggubnya sembabyangku, ibadatku, bidupku, dan matiku banyalah untuk Allab Swt. Tuban semesta alam".

Demikian juga di dalam haji, akan bersikap "labbaika allahumma labbaik ...”. Ini semua menunjukkan adanya sikap kepatuhan dan kepasrahan totalitas hanya kepada Allah Swt. Semata. ${ }^{58}$ Oleh karena itu Syekh Yusuf selalu memperingatkan dan menekankan dalam risalahnya mengenai sumber taubid atau itikad yang harus diyakini; pertama, Qs. al-Ikblas (112): 1-3. Kedua, Qs. asy-Suaraa (26): 11, bahwa Laisa kamitslibi syai'un dalam hal ini Tuhan "tidak dapat disamakan dengan segala sesuatu". Konsep yang terkandung dalam kedua itikad ini ialah bahwa Tuhan adalah Tunggal dan tidak ada sekutu bagi-Nya. ${ }^{59}$

Banyak orang mengatakan bahwa tarekat merupakan salah satu bentuk aplikasi dari kesufian. Sedangkan pandangan Abdurrahim Nur bahwa tidak sulit untuk menilai apakah tarekat termasuk dalam kepasrahan diri kepada Allah Swt. atau tidak. Apa yang dilakukan di dalam tarekat bisa dikatakan sebagai semata-mata menjalankan perintah Allah Swt. dan Rasul-Nya serta apabila tidak ada perintah demikian tentu hal itu merupakan suatu peribadatan yang diada-adakan, dibuat-buat yang dalam istilah agama disebut bid'ah. Kalau mengada-ada berarti bukan sikap mengabdi. Sebab yang disebut mengabdi itu semata-mata menghambakan diri kepada Allah Swt.

Peristiwa di zaman Rasulullah Muhammad Saw. yang bisa dijadikan contoh tentang 'mengabdi' yang artinya 'ibadah'. Nabi Muhammad menyuruh sahabat Ali dan sahabat-sahabat lainnya untuk memerangi kaum kuffar dan kaum musyrikin. Sahabat Ali memang dikenal sebagai sahabat paling berani, Ali sampai di medan pertempuran terjadilah duel dengan pedang. Ali tidak jadi membunuh lawannya. Ia bahkan meninggalkan orang itu. Sehingga para sahabat yang mengetahui peristiwa itu merasa heran. Mereka menegur Ali, "bagaimana Ali justru tidak melakukannya". Ali kemudian menjawab, "jika seandainya sempat membunuh orang itu, yang menyuruh untuk membunuh

${ }^{58}$ Ibid.

${ }^{59}$ Abu Hamid, Syekh Y usuf Seorang Ulama, Sufi dan Pejuang (Jakarta: Obor Indonesia, 2005), 183.

LILmuna Jurnal Studi Keislaman, Volume 17 Nomor 1 (Juni) 2013 
siapa? Apakah membunuh orang itu karena perintah Allah Swt. dan Rasul-Nya ataukah membunuh karena kebencian dan kemarahan? Apa itu merupakan perintah Allah Swt. Jangan sampai melakukan hal itu tidak semata-mata karena Allah Swt." Hal inilah yang dikhawatirkan oleh Ali.

Pesan yang ingin disampaikan dalam contoh peristiwa di atas adalah melakukan ibadah haruslah benar-benar ditujukan kepada Allah Swt. semata. Apabila tercemari oleh kepentingan dan niatan di luar kehendak Allah Swt., maka seharusnya tidak dilakukan. Karena hal itu akan berakibat tidak murninya suatu peribadatan yang pada gilirannya tidak mendatangkan ridha Allah Swt. Hal lain yang menunjukkan suatu sikap ibadah adalah misalnya saat mengerjakan shalat. Lima jari tangan sebelah kiri diletakkan di atas paha pada saat duduk sehabis sujud. Sedangkan lima jari kanan tidak demikian karena jari telunjuk harus diangkat bagaikan orang menunjuk. Karena perintah-Nya demikian maka harus patuh dan ikhlas mengikuti sebagaimana adanya. Itulah yang seharusnya dilakukan karena memang diperintahkan demikian. Dan itu adalah sikap murni karena Allah Swt., mukblis, artinya dengan kejernihan sikap di dalam mengabdi kepada Allah Swt. Ini berbeda halnya ketika menunjukkan tempat seseorang, bisa dengan kelima jari, tetapi tidak demikian saat diperintah di dalam shalat. Inilah suatu kemurnian sekaligus suatu sikap kesufian. ${ }^{60}$

Apa bila seseorang telah melaksanakan ibadah sesuai dengan tuntunan dari Allah Swt., dan Rasul-Nya maka tauhid yang dijalankan adalah tauhid sufi yakni tauhid murni. Orang yang demikian bisa dikatakan telah bertauhid rububiyyah maupun bertauhid ulubiyyah secara murni, dengan kemurnian tauhid rububiyyah dan 'ulubiyyah berarti betul-betul bertauhid murni bertauhid sufi.

Di dalam tarekat, apa pun nama yang dilabelkan pada suatu tarekat yang merupakan aplikasi dari perilaku sufi adalah sah. Yang penting pola sikap dalam beribadah sesuai dengan aturan dari Allah Swt. dan Rasul-Nya maka itu berarti sufi. Kalau tidak demikian maka berarti belum menjadi sufi. Man 'amila amalan laisa 'alaibiamrunaa, fahuwa raddum (al-Hadis). Artinya, barang siapa

${ }^{60}$ Nur, Pergolakan..., 56-7. 
yang melakukan suatu amal yang bukan dariku maka tertolak. Dalam hal ini jika ingin menuju kehidupan sufi harus sesuai dengan aturan Allah Swt. dan Rasul-Nya. ${ }^{61}$

Dalam tarekat Naqsyabandiyah memandang bahwa manusia adalah makhluk yang diamanahkan mengelola bumi atau alam semesta (Qs. Al-Baqarah [2]: 30). Dituntut untuk menggali sebagian rahasia khazanah pengetahuan yang disebut al-ilm, terutama yang berkaitan dengan seluk beluk alam di sekitarnya, termasuk hubungan antara sesama manusia, hubungan antara manusia dengan makhluk hidup yang lain, hubungan dengan alam semesta. Semua itu dilakukan dalam rangka beribadah, penuh ketundukan kepada Allah di mana Dia menyediakan sarana dan sumbernya. Manusia ketika lahir tidak tahu apa-apa, Allah memberinya sarana untuk meraih pengetahuan, yaitu: indera dan akal budi (Qs. An-Nahl [16]: 78). Allah pun menyediakan sumber pengetahuan yang di dalam al-Qur'an disebut ayat, yang berarti tanda atau fenomena. Bila dilakukan klasifikasi, fenomena-fenomena itu ada yang disebut qawliyyah berupa wahyu Allah yang tersurat dalam Qs. Ali Imran (3): 146:

Dan berapa banyaknya Nabi yang berperang bersama-sama mereka sejumlah besar dari pengikut (nya) yang bertakwa. Mereka tidak menjadi lemah karena bencana yang menimpa mereka di jalan Allah, tidak lesu dan tidak (pula) menyerah (kepada musuh). Allah menyukai orangorang yang sabar.

Demikian juga ada yang disebut kawniyyah yang terdapat dalam alam semesta dan diri manusia (Qs. Fussilat [41]: 53):

Kami akan memperlihatkan kepada mereka tanda-tanda (kekuasaan) Kami di segala wilayah bumi dan pada diri mereka sendiri, hingga jelas bagi mereka bahwa al-Qur'an itu adalah benar. Tiadakah cukup bahwa Sesungguhnya Tuhanmu menjadi saksi atas segala sesuatu?.

Dalam beberapa tarekat memang ada yang melakukan amalan zikir sampai mabuk. Mereka menganggap bahwa yang demikian adalah lebih khusyu'. Hal yang demikian dianggap lebih masuk ke jalan kesufian dan karenanya lebih memungkinkan untuk diterima oleh Allah Swt. Bagi Abdurrahim Nur untuk menilai hal yang demikian tidaklah rumit. Persoalannya tinggal mengembalikan pada sikap dan tingkah laku Rasullah

${ }^{61}$ Hadarah Rajab, Kehidupan Sufi (Yogyakarta: Pustaka Book Publisher, 2006), 57. 
Muhammad Saw. itu adalah orang yang sudah sayyidu al-anbiyaa'i wa al-mursalin, khatamin Nabiyyin termasuk orang yang terbaik sementara Nabi Muhammad Saw. tidak pernah wiridan sampai mabuk, Rasulullah Saw. pernah juga menyampaikan cerita tentang seorang perempuan ahli shalat dan shadaqah. Hanya karena lisannya kalau berbicara dengan orang lain selalu membuat sakit hati, ketika ada sahabat bertanya kepada Rasulullah bagaimanakah perempuan itu kemudian Rasulullah menjawab dengan singkat Neraka tempatnya! kalimat singkat tersebut mengandung arti bahwa bagaimanapun baik dan tekunnya seseorang menjalankan ibadah, tetapi jika melanggar tuntunan ibadah lainnya di dalam agama maka sebaiknya ia segera memperbaiki diri agar cita-citanya untuk meraih ridha Allah Swt., dapat terwujud. 62

Ijma' para ulama; fisafat sufi menurut pemahaman Abdurrahim Nur sebenarnya untuk menentukan baik dan buruk di dalam beragama (Islam). Tolok ukur yang digunakan untuk menentukan baik dan buruk ini bukan terletak pada disenangi atau tidak disenangi orang, melainkan tolok ukur yang jelas yakni al-Qur'an dan Sunnah Rasulullah Saw. Oleh karena itu penting memahami Taubid. Menurut Mir Valiuddin, ${ }^{63}$ kaum Sufi dalam tarekat Nasyabandiyah sangat menitik beratkan pentingnya "kontemplasi". Mereka berpandangan bahwa ruh manusia sesungguhnya tidak mempuyai bentuk. Namun jika mengisinya dengan sebuah bentuk maka tidak akan mungkin ada tempat untuk sebuah bentuk lainnya. Untuk mencapai realitas, orang harus memusatkan pikirannya pada realitas itu tanpa terpengaruh oleh aspek apa pun di dunia sekitarnya serta mengarahkan segenap kekuatan pikiran, imajinasi dan persepsi guna menunaikan tugas ini. Itulah sebabnya mereka melarang sang salik mendengarkan sama' (audisi), atau melantunkan zikir dengan suara keras (drikir bi al-jahr). Hal yang demikian ini menurut mereka sebagai "pencarian sia-sia akan hal-hal tak tampak" (ghayb bazl), sebab yang mesti dilakukan adalah menemukan Realitas dalam diri sendiri. Sebagaimana ditegaskan

${ }^{62}$ Nur, Pergolakan..., 63.

63Ibid., 39-40. 
oleh Hadhrat Khawaja Khurd bahwa darwisyi yang tiada lain adalah cara berpikir yang benar.

Jami, sembari memuji para sufi dalam tarekat Naqsyabandiyah mengatakan; Kaum Naqsyabandiyah adalah sekelompok pemimpin luar biasa, mereka bergabung dengan Kafilah menuju tanah suci lewat jalan rahasia. Kaum sufi dalam tarekat ini mendasarkan pandangan mereka pada sebuah hadis yang diriwayatkan dalam Misykat di mana Nabi Muhammad Saw. memberi nasehat Ibn 'Abbas demikian:

Wahai orang-orang muda, pandanglah selalu Allah,

Allah pasti akan memandangmu.

Wahai, Nak, pandanglah selalu Allah,

Kau akan temukan Allah di depanmu. ${ }^{64}$

Pada dasarnya ajaran tarekat Naqsyabandiyah meliputi keselarasan kedua aspek hablun minallah (hubungan manusia dengan Allah SWT) dan bablun minannas (hubungan dengan sesama manusia dan alam), keseimbangan itulah yang dapat menjamin keharmonisan dan kehidupan manusia di muka bumi ini, sebagai suatu persatuan dan kesatuan yang tidak dapat dipisahkan. Melaksanakan salah satu aspek saja tidak akan membuahkan salam, sebagaimana tujuan inti dari agama Islam yakni untuk kemaslahatan umat di dunia dan akhirat. Perjalan spiritual tarekat ini, ialah mendapatkan pengetahuan, supaya dapat pula mengetahui jiwa alam, bangsa dan dasar berfikir untuk bangsa, terutama di kalangan umat Islam karena apabila telah dapat mengetahui terbukalah kesempatan untuk hidup di tengah-tengah mereka dan merasakan sakit dan senang yang mereka rasakan. Dapat mengajak mereka kepada pokok pangkal tasawuf yang sebenarnya, kembali kepada taubid, yaitu bahwa Tuhan hanya Satu (Esa), yang lain adalah alam yang bersifat akan binasa.

Salah satu bentuk praktek tasawuf (tasawuf 'amali) yaitu aliran Tarekat Naqsyabandiyah yang dijalankan dan dikembangkan oleh masyarakat Sulawesi Selatan dasar utamanya adalah merupakan bentuk tasawuf amaliyah, telah menjadi tradisi spiritual yang paling luas dikenal dalam sejarah kebudayaan

${ }^{64}$ Mir Valiuddin, Contemplative Disciplines in Sufisme (London: East-West Publication (UK) Ltd, 1980), 40. 
agama Islam. Berpijak pada sumber utamanya yakni al-Qur'an dan al-Hadis Nabi Muhammad Saw. Kecenderungan mistisisme kaum Muslim telah memainkan peranan penting dalam sejarah keyakinan umat Islam baik dalam perkembangan pribadi maupun kolektif. Tarekat pada awalnya merupakan ilmu yang diajarkan khusus oleh Rasulullah Saw. berasal dari thariqatussirriyah merupakan amalan yang masih berbentuk rahasiah di kalangan para sahabat, kemudian berkembang menjadi lembaga atau organisasi peramalan zikir. Perilaku Nabi Muhamamd Saw. merupakan cikal bakal dari peramalan tasawuf tarekat yang kemudian dilanjutkan peramalannya oleh Ablul bait, Khulafaur Rasyidun dan para sahabat yang lain, para ablulsh Shufah, pada salafush shaleh, zaman tabi'in, tabi'it tabiin sampai dengan zaman sekarang.

Para Syekh golongan sufi telah membangun kaidah-kaidah mereka di atas prinsip tauhid yang shahih. Mereka telah membuat kaidah tersebut jauh dari bid'ah, relevan dengan ajaran taubid yang telah diwariskan oleh generasi salaf dan abli sunnah. Tidak ada rekayasa atau penyimpangan di dalamnya. Mereka mengetahui yang menjadi hak Allah, dan mereka telah membuktikan hal-hal yang menjadi predikat wujud, dari segala yang tiada. Karena itu, al-Junayd r.a. pemuka tarekat ini berkata tauhid adalah menunggalkan yang Maha dahulu (qidam) dari yang datang kemudian (buduts). ${ }^{65}$

\section{Catatan Akhir}

Ditetapkan dengan firman Allah Swt. ada tiga kedudukan tinggi bagi orang yang mencapai derajat ini: Pertama, ia bebas dari perhitungan di hari Masyar dan kehadirannya di sana firman Allah Swt. dalam Qs. as-Shaffat (37): 127-128:

Maka mereka mendustakannya, karena itu mereka akan diseret ke neraka, kecuali hamba-hamba Allah Swt. yang dibersihkan dari dosa.

Hal di atas terjadi demikian sebab kelompok ini telah melakukan perhitungannya dengan perantaraan melewati kiamat besar yang ada pada jiwa (al-qiyamah al-kubra' al-anfusiyab). Maka,

${ }^{65} \mathrm{Al}$-Qusyairy Iman An-Naisabury, Ar-risalah Qusyariyah Fi Tlmi at- Tasha wufi, ter. Mohammad Luqman Hakiem, Risalabtul Qusyairiyah (Surabaya: Risalah Gusti, 1996), 7. 
mereka tidak memerlukan perhitungan yang lain. ${ }^{66}$ Sesungguhnya pahala dan kebahagiaan yang diberikan kepada seseorang biasanya disesuaikan dengan amalnya kecuali kelompok manusia ini, dimana kemuliaan dan berbagai karunia terdapat di belakang amal mereka dan di atas pahala perbuatan mereka firman Allah Swt. dalam Qs. as-Shaffat (37): 39-40: "Dan kamu tidak diberi pembalasan melainkan terhadap apa yang telah kamu kerjakan. Kecuali hamba-hamba Allah SWT. yang dibersihkan dari dosa". Wa al-Lāh a lam bi al-șawäb.

\section{Daftar Pustaka}

Abu Hamid. 2005. Syekh Yusuf Seorang Ulama, Sufi, dan Pejuang. Jakarta: Obor Indonesia.

Bakhtiar, Amsal. 2004. Filsafat Ilmu. Jakarta: Raja Grafindo Persada.

Al-Ghazali, Abu Hamid. 1964. Al-Misykat al-Anwar. Kairo: Abu al'Ala Affifi. . tt. Al-Munqiz min al-Dalal. Beirut: al-Sya'biyah.

Hadiwijono, Harun. 1980. Sari Sejarah Filsafat Barat. Yogyakarta: Kanisius.

Hidayat, Komaruddin. 1995. Agama Masa Depan: Perspektif Filsafat Perenial. Jakarta: Paramadina.

Hilal, Ibrahim. 1997. Tasawnf antara Agama dan Filsafat. ter. Ija Suntana, E. Kusdian. Bandung: Pustaka Hidayat.

Al-Jabiri, Mohamed Abed. 2004. Problem Peradaban: Penelusuran atas Jejak Kebudayaan. t.tp: tp.

John, Espisito L. 2002. Ensiklopedi Oxford: Dunia Baru Islam. ter. Eva Y.N. dkk. Bandung: Mizan.

K. Bertrand, Russell. 2001. Sejarah Filsafat Barat dan Kaitannya dengan Kondisi Sosio-Politike dari Zaman Kuno bingga Sekarang. ter. Sigit, dkk. Yogyakarta: Pustaka Pelajar.

al-Naisabury, Al-Qusyairy Iman. 1996. Risalah Qusyariyah. ter. Mohammad Luqman Hakiem. Surabaya: Risalah Gusti.

${ }^{66}$ Muhammad Husain Ath-Thabathabaiy Al'allamah Asy-Syayyid, AlMizan Fi Tafsir Al-Qur'an (Baerut: Muhassasah Al-A'lamiy Limathbu'ah, t.t), 50 . 
Nasr, Syeed Hussein. 1980. Living Sufism. London: Paperback.

Noeng, Muhadjir. 2000. Metode Penelitian Kualitatif. Yogyakarta: Rake Sarasin.

Nur, Abdurrahim. 2003. Pergolakan Mubammadiyah Menuju Sufi. Yogyakarta: Hikam Press.

Rajab, Hadarah. 2006. Kehidupan Sufi. Yogyakarta: Pustaka Book Publisher.

Smith, Margaret. 1979. Rabi'a the Mystie and Her Fellow-Saints in Islam. London: Cambridge Univercity Press.

Sumantri, Jujun S. 2003. Filsafat Ilmu Sebuah Pengantar Populer. Jakarta: Pustaka Sinar Harapan.

Syukur, Amin. 2002. Menggugat Tasawuf. Yogyakarta: Pustaka Pelajar.

Tafsir, Ahmad. 1992. Filsafat Umum. Bandung: Remaja Rosdakarya.

al-Ṭabațabaī, al-'Allāmah al-Sayyid Muḥammad Husain. tt. AlMižàn fi Tafsì al-Qur'ān. Baerut: Muhassasah al-'Alamī Limațu'ah.

Valiuddin, Mir. 1980. Contemplative Disciplines in Sufisme. London: East-West Publication (UK) Ltd. 